\title{
Morphological and anatomical studies on some taxa of family Apocynaceae
}

\author{
M. A. El-Fiki ${ }^{1}$, A. M. El-Taher ${ }^{1}$, A. G. EL-Gendy ${ }^{2}$ and M. I. Lila 1, 2, \\ ${ }^{1}$ Department of Agricultural Botany, Faculty of Agriculture, Al-Azhar University, Cairo, Egypt \\ ${ }^{2}$ National Research Centre, Dokki, Giza, Egypt \\ *Correspondence: mahmoudlila83@azhar.edu.eg (M. Lila)
}

\begin{abstract}
Apocynaceae is one of the important families that is present all over the world. The aim of this study is to provide some anatomical features of 7 species that represent 7 genera belonging to 4 subfamilies (Apocynoideae, Asclepiadoideae, Periplocoideae and Rauvolfioideae) related to Apocynaceae. The species samples were collected from different areas in Egypt. The study was focus on the morphological and anatomical characters of stems and leaves. The results were recorded in the form of comparison between the examined plants. Most of these plants are perennial herbs as in Cynanchum acutum L. but some are shrubs as in Carissa spinarum L. and trees as in Alstoniascholar is R.Br. The stem is woody in some of the investigated plants as in Alstoniascholaris R.Br. and succulent in some plants as in Pachypodium lamerei. The leaves are simple, spirally, opposite and opposite decussate. Leaves shape are ovate, elliptic, oblonglanceolate or cordate with entire margin. The vascular bundles in all of the examined plants are bicollateral. From the analysis of all the available data by using the Multi Variate Statistical Package (MVSP) Program it could be stated that Apocynaceaeand Asclepiadaceae are very similar to each other which could be ranked in one large family Apocynaceae. In conclusion, we emphasize the previous recommendations to merge both Apocynaceae and Asclepiadaceae families in one large family, that is Apocynaceae.
\end{abstract}

Keywords: Morphology; Anatomy; Asclepiadoideae; Periplocoideae; Rauvolfioideae; Apocynaceae.

\section{INTRODUCTION}

Apocynaceae is one of the important families that is present all over the world. It includes five important sub families; Apocynoideae, Asclepiadoideae, Periplocoideae, Rauvolfioideae and Secamonoideae (Endress and Bruyns 2000). It is considered one of the medium sized families of the flowering plants as it includes 215 genera including 1900 species that spread all over the world. Also, Asclepiadaceae is an important family. It includes 315 genera including 2900 species that spread all over the world (Boulos, 2000). Some authors consider them as two distinct families: Apocynaceae and Asclepiadaceae (Dahlgren, 1980; Cronquist, 1981; Takhtajan, 1987; Rosatti, 1989). Others still consider them as one large family Apocynaceae (Judd et al., 1994; Struwe et al., 1994; Sennblad and Bremer, 1996; Endress and Bruyns 2000). Apocynaceous plants are herbs, shrubs or trees and perennial or very rarely annual (Muschler, 1912; Bailey, 1949; Boulos, 2000; Koyuncu, 2012; Venkateshwar et al., 2013). The stem was erect, climbing or twining and trete or 4 angled (Bolos, 2000; Rodda and Simonsson, 2011; Sidney, 2012). The leaves are simple, alternate, opposite or whorled. Leaves shapes are ovate, obovate, oblong, linear, lanceolate or elliptic and their margin are entire or undulate with acute apex. The leaf is petiolate or sessile (Hutchinson 1973; Jafri 1966; Migahid and Hammouda 1974; ElGazzar and Hamza 1980; Boulos, 2000; Kidyoo, 2014; Bibi et al., 2015). The cortex is consisting of hypodermal collenchyma of thick-walled followed by slightly thick-walled parenchyma (816 rows) containing cluster crystals of calcium oxalate. (Al-Massarani, 2011). The palisade parenchyma is 3-layered at the adaxial side and 1-layered at the abaxial side of the lamina. The spongy parenchyma is 10-13 layered, with long armed cells. The vascular system is bicollateral. (Formiga et al., 2011).

The aim of this study is to provide some anatomical features of some species of family Apocynaceae.

\section{MATERIALS AND METHODS}

\section{Morphological studies \\ Sample of plants}

This work was carried out in the Department of Agricultural Botany, Faculty of Agriculture, Al-Azhar University, Nasr city, Cairo, Egypt. Seven species belonging to 7 genera of Apocynaceae were collected from three different places: Al-Azhar University (Az), El- Orman Garden (Or) and flower exhibition (Fl).

\section{Identification}

Identification of the collected plants was achieved by comparing their morphological characters with the characters of the previously identificated plants as published by (Tächolm, 1974; Migahid and Hammouda, 1974; Boulos, 2005). 


\section{Anatomical studies}

In laboratory, from young parts of the plant, samples of $1 \mathrm{~cm}$ long from the middle part of the technical length of the stem and $1 \mathrm{~cm}^{2}$ from leaf was taken. Samples were dehydrated in a series of solutions of ascending concentrations of ethyl alcohol varying from $50 \%$ to $100 \%$ ethyl alcohol. The samples then embedded in paraffin wax [m.p. $58-61^{\circ} \mathrm{C}$ ] using xylol as a solvent. By using rotary microtome, sections were cut at the thickness of $15 \mu \mathrm{m}$ and then mounted on slides with the aid of egg albumin as an adhesive. Wax dissolved in xylol and the slides were passed through descending series of ethyl alcohol solutions varying from $100 \%$ to $50 \%$ ethyl alcohol concentrations in descending order. The sections were stained with safranin and light green, and then the colored sections were kept as permanent preparations on the slides with Canada balsam as mounting medium (Nassar and Sahhar, 1998). All photographs were prepared by Nikon Camera on a Carl Zeiss Jena microscope photographs.

Multi Variate Statistical Package Programme (MVSP) was used to analyse the morphological and anatomical data (Sneath and Sokal 1973).

\section{RESULTS AND DISCUSSION}

\section{Morphological observation habit}

All the investigated plants of family Apocynaceae are perennial and evergreen except the plants of Pachypodium lamerei Drake. Which are deciduous. Some of the examined plants are herbs as in Cynanchum acutum L. (Fig. 1A), few plants are trees as in Alstonia scholaris R.Br. and shrubs in Carissa spinarum L. only. These results are in agreement with those obtained by (ElGazzar and Hammouda, 2006; Bibi et al., 2015) who recorded that Apocynaceae plants were herbs, shrubs or trees and perennial.

\section{Stem}

The stem is aerial and long in all the examined plants. It is woody in some of the investigated plants as in Carissa spinarum L., herbaceous in some of the plants as in Cynanchum acutum L. and succulent in Pachypodium lamerei Drake. only (Fig. 1C). It is erect in most of the examined plants as in Alstonia scholaris R.Br. and weak in some plants as in Cynanchum acutum L. (Fig. 1B) The texture of stem is smooth in all the plants, except Pachypodium lamerei Drake. are spiny (Fig. 1C). All the plants are monopodial branching, except Pachypodium lamerei Drake. which isapicale. The monopodial branching is uni-lateral in some plants as in Alstonia scholaris R.Br. and bi-lateral in some plants as in Beaumontia grandiflora wall. The stem is solid in most of the plants as in Beaumontia grandiflora Wall. And hollow in some plants as in Stephanotis floribunda Brongn. Similar results are reported by (Hutchinson, 1973; Boulos, 2000; Sidney, 2012; El-Kashef et al., 2015) who observed that the stem of Apoynaceae was erect or twining, trete or 4 angled and glabrous or hairy.

\section{Leaves}

The leaves are present in all the examined plants. Leaves are simple and cauline in all the plants (Fig. $1 \mathrm{H})$. All the investigated plants are exstipulate except Carissa spinarum L. which is stipulate (Fig.1 D). Leaves are petiolate in all the plants (Fig. 1E). The leaf base is epulvinate in all the plants except in Cryptostegia grandiflora $\mathrm{R} \mathrm{Br}$. they are pulvinate. The leaves arrangement is spirally in some plants as in Pachypodium lamerei Drake. (Fig. 1C), opposite in some plants as in $C$. spinarum L. (Fig. 1I) and opposite decussate in some plants as in Beaumontia grandiflora Wall. (Fig. 1J). The leaf shape is cordate in Cynanchum acutum L. only (Fig. 1E), elliptic in Alstonia scholaris R.Br. only (Fig. 1G), oblong lanceolate in Pachypodium lamerei Drake. only (Fig. 1F) and ovate in some plants as in Carissa spinarum L. (Fig. 1D). The shape of leaf apex is acuminate in some of the plants as in Beaumontia grandiflora Wall. (Fig.1 H), obtuse in Stephanotis floribunda Brongn only, caudate in Pachypodium lamerei Drake. (Fig. $1 F)$ only and mucoronta in Cynanchum acutum L. only (Fig. 1E). The shape of leaf base is acute in some of the plants as in Pachypodium lamerei Drake. (Fig. 1F), rounded in some of the plants as in Carissa spinarum L. (Fig. 1D) and cordate in C. acutum L. only (Fig. 1E). The venation of the leaf is pinnate reticulate in all the plants (Fig. 1G) except in C. acutum L., it is palmate reticulate (Fig. $1 \mathrm{E})$. The color of leaf midrip is white in some of the plants as in Alstonia scholaris R.Br. (Fig. 1G) and green in some of the plants as in Beaumontia grandiflora Wall. (Fig. 1H). The lateral venation of the leaf is distinict in some of the studied plants as in Beaumontia grandiflora Wall. (Fig. 1J) and indistinict in some of the plants as in Carissa spinarum L. (Fig. 1I). The margin of the leaves is entire in all the examined plants. These results are in harmony with the findings of (Hutchinson, 1973; Migahid and Hammouda, 1974; El-Gazzar and Hamza, 1980; Gabr et al., 2015) who mentioned that the leaves of Apocynaceaeas were opposite, alternate, opposite decussate or whorled. The leaf was sub sessile or petiolate. The leaf shapes were elliptic, ovate, linear or cordate. The blade apex was acute, apiculate, obtuse or acuminate. The blade texture was glabrous or tomentose. 


\section{Anatomical observation}

\section{Stem anatomy}

The stem varies in the external shape. It is rounded in some of the examined plants as in Stephanotis floribunda Brongn. (Fig. 2A) and ovate in some of the plants as in Cryptostegia grandiflora R.Br. (Fig. 2B).

\section{Epidermis}

The epidermal cells are covered by cuticle layer. The cuticle layer is thin in some of the examined plants as in Cynanchum acutum L. (Fig. 2D) and thick in most of the plants as in Carissa spinarum L. (Fig. 2C). The multiepidermis is present in few plants as in Cynanchum acutum L. (Fig.2 D) but it is simple in most of the plants as in Carissa spinarum L. (Fig. 2C). The cork and lenticels are observed in most of the plants as in Pachypodium lamerei Drake. (Fig.2F) and Alstonia scholaris R.Br. (Fig. 2G) respectively. Similar results were reported by (Akyalcin et al.,2006; Poornima et al., 2009; Al-Massarani, 2011; ElKashef et al., 2015) who found that the epidermis of Apocynaceae was semi-circular in cross section with one or two epidermal layers. The cork was formed of 2-3 layers of thin walled cells.

\section{Cortex}

The cortex consists of aerenchymatous tissuein some of the examined plants as in Alstonia scholaris R.Br. also storage parenchymatous tissue is observed in most of the plants as in Pachypodium lamerei Drake. (Fig. 2E). Collenchymatous cells are shown in most of the plants as in Beaumontia grandiflora Wall. (Fig. 2H), sclerenchymatous cells are observed in Alstonia scholaris R.Br. only and the water storage cells are noticed in Pachypodium lamerei Drake. only (Fig. 2I). Cortical vascular bundles are present in Alstonia scholaris R.Br. only (Fig. 3J). Rosette crystals are noticed in most of the studied plants as in Beaumontia grandiflora Wall. (Fig. 3K), prismatic crystals are shown in most of the plants as in Carissa spinarum L.; sandy crystals are also noticed in few of the plants as in Alstonia scholaris R.Br. Resin canals are observed in most of the plants as in Cynanchum acutum L. (Fig. 3L). Laticifers canals are shown in few of the plants as in Pachypodium lamerei Drake. (Fig. 3M). Secretory cells and canals are noticed in some of the plants as in Carissa spinarum L. (Fig. 2C) and secretory cavities are observed in few plants as in Pachypodium lamerei Drake. (Fig. 3N). These results are in harmony with the findings of (Akyalcin et al., 2006; Poornima et al., 2009; AlMassarani, 2011; Duarte and Larrosa, 2011; Bibi et al., 2015; El-Kashef et al., 2015) who stated that the cortex of the stem of Apocynaceae plants was consisted of collenchyma of thick walled polyhedral elongated cells followed by slightly thick walled parenchyma (8-16 rows) and containing cluster crystals of calcium oxalate. The endodermis was formed of elongated cells. Latex tubes were present in the cortex region.

\section{Pericycle}

Parenchymatous and collenchymatous cells are noticed in most of the plants as in Beaumontia grandiflora Wall. (Fig. 2H). Rosette are crystals observed in some of the taxa as in Beaumontia grandiflora Wall. Similar results were reported by (Al-Massarani, 2011; Duarte and Larrosa, 2011; El-Kashef et al., 2015) who reported that the pericycle of Apocynaceae plants was formed of Parenchymatous cells.

\section{Vascular bundles}

Vascular bundles of all the examined plants are bicollateral and present in complete ring in most of the plants as in Cryptoste giagrandiflora R.Br. or in group in Pachypodium lamerei Drake. only. The vessels are shown in chains in all of the plants (Fig. 3O) except Pachypodium lamerei Drake. which isclusters (Fig.3 P). Tyloses are observed in some plants as in Cynanchum acutum L. (Fig. 3Q). These results are in agreement with those obtained by (Akyalcin et al., 2006; AlMassarani, 2011; Duarte and Larrosa, 2011; ElKashef et al., 2015) who recorded that the vascular bundles of Apocynaceae plants were bicollateral bundles.

\section{Xylem}

Rosette crystals are noticed in some plants as in Cynanchum acutum L. Resin canals are present in few of the plants as in Alstonia scholaris R.Br. (Table 3). Anatomical observation of medulary rays revealed the presence of sclerenchyma tissues in most of the plants as in Alstonia scholaris R.Br. and collenchyma tissues in few of the plants as in Beaumontia grandiflora Wall. (Table3). Rosette crystals are recorded in Cynanchum acutum L. and Stephanotis floribunda Brongn. only (Table 3). Resin canals and secretory cells present in some plants as in Alstonia scholaris R.Br. Similar results were reported by (Poornima et al., 2009; Al-Massarani, 2011; El-Kashef et al., 2015) who found that the xylem of Apocynaceae plants was formed of thick walled elements consisting of vessels, fibres, tracheids and xylem parenchyma and separated by 2-9 rows of medullary rays. The medullary rays were uni or multi-seriate and formed of polygonal, thick walled cells

\section{Phloem}

Rosette crystals are observed in some of the examined plants as in Cynanchum acutum L. and sandy crystals are noticed in Alstonia scholaris R.Br. only (Table3). Resin canals are present in 
most of the plants as in Cynanchum acutum L. Secretory cells are noticed in few plants as in Alstonia scholaris R.Br. These results were in agreement with (Al-Massarani, 2011; El-Kashef et al., 2015) who recorded that the phloem of Apocynaceae plants was narrow and composed of sieve tubes, companion cells and phloem parenchyma. The phloem parenchyma cells were polygonal in shape. The medullary rays were uniseriate or biseriate and consisting of elongated parenchyma.

\section{Pith}

Pith is solid in most of the studied plants as in Cryptostegia grandiflora R.Br. and hollow in few plants as in Stephanotis floribunda Brongn. Aerenchymais observed in most of the plants as in Cryptostegia grandiflora R.Br. Also, storage parenchyma noticed in Pachypodium lamerei Drake. only (Table3). Sclerenchymatous cells are recorded in Alstonia scholaris R.Br. only (Table 3). Rosette crystals are noticed in some of the plants as in Stephanotis floribunda Brongn. (Table 3), prismatic crystals are shown in some plants as in A. scholaris R.Br. (Table 3). Secretory cells and canals are noticed in few plants as in Alstonia scholaris R.Br. and secretory cavities are present in P. lamerei Drake. only (Table 3). These results were in harmony with the findings of (Poornima et al., 2009; Al-Massarani, 2011; Duarte and Larrosa 2011) who mentioned that the pith of stem of Apocynaceae was formed of large rounded, water storing cells, thin walled parenchymal cells containing numerous starch granules and prisms of calcium oxalate.

\section{Leaf anatomy}

\section{Epidermis}

The upper epidermal cells are covered by cuticle layer. The cuticle layer is thin in most of the examined plants as in Cryptostegia grandiflora R.Br. (Fig. 4S), and thick in some plants as in Alstonia scholaris R.Br. (Fig. 4R). Resin canals are observed in few plants as in Alstonia scholaris R.Br. The lower epidermal cells are covered by cuticle layer. The cuticle layer is thin and smooth in all of the examined plants. Similar results were reported by (Poornima et al., 2009; Albert et al., 2011; Duarte and Larrosa, 2011) who cited that the epidermis was single layered in Apocynaceae plants.

\section{Mesophyllic tissue}

The mesophylic tissue consists of spongy and palisade in all the examined plants. The palisade tissue is one row in most of the studied plants as in Cryptostegia grandiflora R.Br. and more than one row in some of the plants as in Carissa spinarum L. The palisade tissue is continuous in most of the plants as in Carissa spinarum L. but it is separated in some of the plants as in Cryptostegia grandiflora $\mathrm{R} . \mathrm{Br}$. The palisade tissue is monolateral in all plants. Mucilage cells are noticed in few plants as in Carissa spinarum L. (Fig. 4T). Rosette crystals are observed in most taxa as in Carissa spinarum L. Resin canals are present in Alstonia scholaris R.Br. only. Laticifers and secretory cells are present in some of the plants as in Carissa spinarum L. (Fig. 4T), secretory canals are noticed in Stephanotis floribunda Brongn. only.

Spongy tissue is noticed in all the examined plants. Aerenchymatous cells and armed parenchymatous cells are noticed in most of the plants as in Carissa spinarum L. (Fig. $4 \mathrm{~T}$ and $4 \mathrm{U}$ ). Rosette crystals and resin canals are recorded in some of the plants as in Beaumontia grandiflora Wall. (Fig. 4V). Secretory cells are showed in few of the plants as in Carissa spinarum L. These results were in harmony with the findings of (Poornima et al., 2009; Duarte and Larrosa, 2011; Formiga et al., 2011; Bibi et al., 2015) who observed that the mesophyllic tissue was consisted of palisade and spongyin Apocynaceae plants.

\section{Midrib region}

Midrib regionis convex in the lower surface of the leaf in most of the studied plants as in Beaumontia grandiflora Wall. (Fig. 4W) but straight in Cryptostegia grandiflora R.Br. only (Fig. 4X). Midrib regionis convex in the upper surface of the leaf in Cynanchum acutum L. (Fig. 4Y), straight in few of the examined plants as in Cryptostegia grandiflora R.Br. (Fig. 4X) and concave in Carissa spinarum L. only (Fig. 4Z). Aerenchymatous cells are noticed in some plants as in Carissa spinarum L., palisade is present in some of the plants as in C. spinarum L. and collenchymatous cells are observed in most of the plants as in Cynanchum acutum L. (Table 3). Rosette crystals are noticed in most of the taxa as in Beaumontia grandiflora Wall. Resin canals are present in most of the plants as in Pachypodium lamerei Drake. Secretory cells are noticed in some plants as in Carissa spinarum L.

\section{Vascular bundles}

Vascular bundles are bicollateral in all examined plants. The shape of vascular bundles is crescent in Beaumontia grandiflora Wall. (Fig. 4W), straight in Cryptostegia grandiflora R.Br. (Fig. $4 \mathrm{X}$ ) and semi ring in Alstonia scholaris R.Br. only (Fig. 4a).

\section{Phloem}

Rosette crystals and resin canals are noticed in some of the examined plants as in Cynanchum acutum L. and Alstonia scholaris R.Br. respectively. Similar results were reported by (Inamdae et al., 1975; Albert et al., 2011; Duarte and Larrosa, 2011; 
Formiga et al., 2011) who cited that the vascular bundles were bicollateral in Apocynaceae plants.

It is obvious from the dendrogram that the studied species were divided in to four clusters based on the similarity between them. The first cluster contains two species Beaumontia grandiflora Wall. and Pachypodium lamerei Drake. at similarity (23.062). The second cluster included two species Cynanchum acutum L. and Stephanotis floribunda Brongn. at similarity (26.425). Both clusters were united together at similarity (36.995) the third cluster included two species Alstonia scholaris R.Br. and Carissa spinarum L. at similarity (36.995). The last cluster included one species Cryptostegia grandiflora R.Br. This cluster is similar to the previous three clusters at similarity (42.280). All clusters are similar to each other at similarity (53.811), because all the studied species were belonging to one family Apocynaceae.

\section{Conclusion}

In conclusion, we emphasize the previous recommendations to merge both Apocynaceae and Asclepiadaceae families in one large family, that is Apocynaceae.

\section{REFERENCES}

Akyalcin H., Özen, F., Dülger, B., 2006. Anatomy, morphology, palynology and antimicrobial activity of Amsonia orientalis Decne. (Apocynaceae) growing in Turkey. Int. J. Bot. 2 (1), 93-99.

Albert, S., Padhiar, A., Gandhi, D., Nityanand, P., 2011. Morphological, anatomical and biochemical studies on the foliar galls of Alstonia scholaris (Apocynaceae). Revista Bras. Bot. 34 (3), 343-358.

Al-Massarani, S.M., 2011. Pharmacognostical and Biological Study of Caralluma sinaica Growing in Saudi Arabia. Fac. Pharm. King Saud Univ., Riyadh, p.184-103.

Bailey, L. H. 1949. Manual of cultivated plants. 2nd ed., Mac Millon \& Ltd., NY.

Bibi, H., Afzal, M., Kamal, M., Sohail, I.U., Khan, S.M., Sher, A.A., Ziaulhaq, I.U., Ali, A., Khan, S.A., Ur Rahman, I., 2015. Morphological and anatomical characteristics of selected dicot xerophytes of district Karak, Khyber Pakhtunkhwa, Pakistan. Middle-East J. Sci. Res. 23 (4), 545-557.

Boulos, L., 2000. Flora of Egypt. AL Hadara Publishing, Cairo. Cronquist, A., 1981. An Integrated System of Classification of Flowering Plants. Columbia University Press, NY.

Dahlgren, R.M.T., 1980. General aspects of angiosperm evolution and macrosystematics. Nordic J. Bot. 3, 119149.

Duarte, M.R., Larrosa, C.R.R., 2011. Morpho-anatomical characters of the leaf and stem of Mandevilla coccinea (Hook. et Arn.) Woodson, Apocynaceae. Braz. J. Pharm. Sci. 47 (1), 137-144.

El-Gazzar, A., Hamza, M.K., 1980. The subdivision of Asclepiadaceae. Phytologia, 45 (1), 1-16.

El-Gazzar, A., Hammouda, A.A., 2006. Nine revived records to the flora of Egypt. Egypt. J. Biol. 8, 74-80.

El-Kashef, D.F., Hamed, A.N.E., Khalil, H.E., Kamel, M.S., 2015. Morphological and anatomical studies of the stem of Pachypodium lamerei Drake, family Apocynaceae, cultivated in Egypt. J. Pharmacogn. Phytochem. 3 (5), 25-31.

Endress, M.E., Bruyns, P.V., 2000. A revised classification of Apocynaceae sl. Bot. Rev. 66, 1-56.

Formiga, A.T., Soares, G.L.G., Isaias, R.M.S., 2011. Responses of the host plant tissues to gall induction in Aspidosperma spruceanum Müell. Arg. (Apocynaceae). Am. J. Plant Sci. 2, 823-834.

Gabr, D.G., Khafagi, A.A.F., Mohamed, A.H., Mohamed, F.S., 2015. The significance of leaf morphological characters in the identification of some species of Apocynaceae and Asclepiadaceae. J. Am. Sci. 11 (6), $61-70$.

Hutchinson, J., 1973. The Families of Flowering Plants. 3rd ed., Clarendon Press, Oxford.

Inamdar, J.A., Patel, R.C., Gangadhara, M., Balakrishna, A., 1975. Leaf anatomy of Catharanthus roseus (Apocynaceae) infected with mycoplasm. Phyton (Austria). 17, 151-158.

Jafri, S.K.H., 1966. The Flora of Karachi (Coastal West Pakistan). The Book Corporation, Nizamsons, Karachi.

Judd, W.S., Sanders, R.W., Donoghue, M.J., 1994. Angiosperm family pairs: Preliminary phylogenetic analysis. Harvard Pap. Bot. 5, 1- 51.

Kidyoo, M., 2014. Ceropegia suddeei sp. nov. (Apocynaceae, Asclepiadoideae) from northeastern Thailand. Nordic J. Bot. 32, 569-574.

Koyuncu, M., 2012. A new species of Vinca (Apocynaceae) from eastern Anatolia, Turk. J. Bot. 36, 247-251.

Migahid, A.M., Hammouda, M.A., 1974. Flora of Saudi Arabia. National Enterprises, Riyadh. p. 221-231.

Muschler, K., Ascherson, P., Schweiiifurth, O., 1912. A Manual Flora of Egypt. Vol. II. Friedlaender \& Sohn, Karlstrasse, Berlin. pp. 733-757.

Nassar, M.A., El-Sahhar, K.F., 1998. Botanical preparation and Microscopy (Microtechnique), Academic Bookshop, Dokki, Giza, Egypt. (In Arabic). p. 219.

Poornima, N., Umarajan, K.M., Babu, K., 2009. Studies on anatomical and phytochemical analysis of Oxystelma esculentum (L.f.) R.br. Ex Schltes. Bot. Res. Int. 2 (4), 239-243.

Rodda, M., Simonsson, N., 2011. Hoya rotundiflora (Apocynaceae, Asclepiadoideae), a new horticulturally important species from Myanmar. Phytotaxa. 27, 37-43.

Rosatti, T.J., 1989. The genera of suborder Apocynineae (Apocynaceae and Asclepiadaceae) in the southeastern United State. J. Arnold Arbor. 70, 307401 .

Sennblad, B., Bremer, B., 1996. The familial and subfamilial relationships of Apocynaceae and Asclepiadaceae evaluated with $r b c \mathrm{~L}$ data. Plant Syst. Evol. 202, 153175.

Sidney, N.C., 2012. A Taxonomic Revision of Finlaysonia and Streptocaulon (Periplocoideae; Apocynaceae). Fac. Natural Agric. Sci., Univ. Free State Bloemfontein, South Africa.

Sneath, P.H., Sokal, R.R., 1973. Numercal Taxonomy. The Principles and Numerical Classification. 1st ed., W.H. Freeman, SF

Struwe, L., les ClaAlbert, V.A., Bremer, B., 1994. Cladistics and family level classification of Gentianales. Cladiarstics. 10, 175- 206.

Tãckholm, V., 1974. Students' flora of Egypt. 2nd ed., Cairo Univ. Publication, Corporative Printing Co., Beirut.

Takhtajan, A. 1987. Systema Magnoliophytorum. Leningrad, Nauka.

Venkateshwar, C., Rao, S.G., Kumar, R.S., 2013. Epidermal study of medicinal plants with special reference to identification, adulteration and authentification of crude leaf drugs. Ann. Phytomed. 2 (1), 115-125. 
Table 1. Scientific names and collected sites of species of family Apocynaceae.

\begin{tabular}{lcc}
\hline No. & Family: Apocynaceae & Collected sites \\
\hline Sub family: Apocynoideae & Or \\
1 & Beaumontia grandiflora Wall. & $\mathrm{Fl}$ \\
2 & Pachypodium lamerei Drake. & \\
Sub family: Asclepiadoideae & $\mathrm{Az}$ \\
3 & Cynanchum acutum L. & $\mathrm{Fl}$ \\
4 & Stephanotis floribunda Brongn. & \\
Sub family: Rauvolfioideae & Or \\
5 & Alstonia scholaris R.Br. & Or \\
$6 \quad$ Carissa spinarum L. & Or \\
Sub family: Periplocoideae & Oryptostegia grandiflora R.Br. & \\
7 & & \\
\hline
\end{tabular}

Table 2. List of 86 characters and character states recorded for 7 species representing 7 genera belonging to family Apocynaceae.

\begin{tabular}{|c|c|c|c|}
\hline \multicolumn{4}{|c|}{ A Qualitative characters } \\
\hline \multicolumn{4}{|c|}{ Habit } \\
\hline 1 & Habit & Evergreen $(+)$ & Deciduous $(-)$ \\
\hline \multicolumn{4}{|c|}{ Stem } \\
\hline 2 & Growth habit & Erect $(+)$ & Weak (-) \\
\hline 3 & Texture & Smooth $(+)$ & Spiny (-) \\
\hline 4 & Stem anatomy & Solid (+) & Hollow (-) \\
\hline 5 & Branching & Monopodial (+) & Apical (-) \\
\hline 6 & Branching status & Uni-lateral $(+)$ & Bi-lateral (-) \\
\hline \multicolumn{4}{|c|}{ Leaf } \\
\hline 7 & Stipules & Stipulate $(+)$ & Exstipulate (-) \\
\hline 8 & Base & Pulvinate $(+)$ & Epulvinate (-) \\
\hline 9 & Venation & pinnate $(+)$ & palmate $(-)$ \\
\hline 10 & Midrip color & White (+) & green $(-)$ \\
\hline 11 & Lateral venation & Distinict $(+)$ & indistinict (-). \\
\hline \multicolumn{4}{|c|}{ Anatomical characters } \\
\hline \multicolumn{4}{|c|}{ Stem anatomy } \\
\hline \multicolumn{4}{|c|}{ Epidermis } \\
\hline 12 & Cuticle layer & thick (+) & thin $(-)$. \\
\hline 13 & Epidermal layer & Simple (+) & multiple (-). \\
\hline 14 & Cork & present $(+)$ & absent (-). \\
\hline 15 & Lenticels & present $(+)$ & absent (-). \\
\hline \multicolumn{4}{|c|}{ Cortex } \\
\hline 16 & Aerenchyma tissue & Present (+) & absent (-). \\
\hline 17 & Storage parenchyma tissue & present $(+)$ & absent (-). \\
\hline 18 & Collenchyma tissue & Present $(+)$ & absent (-). \\
\hline 19 & Sclerenchyma tissue & present $(+)$ & absent (-). \\
\hline 20 & Water storage cells & present $(+)$ & absent (-). \\
\hline 21 & Cortical vascular bundles & present $(+)$ & absent (-). \\
\hline 22 & Rosette crystals & present $(+)$ & absent (-). \\
\hline 23 & Prismatic crystals & present $(+)$ & absent (-). \\
\hline 24 & Sandy crystals & present $(+)$ & absent (-). \\
\hline 25 & Resin canals & present $(+)$ & absent (-). \\
\hline 26 & Laticifer tissue & present $(+)$ & absent (-). \\
\hline 27 & Secretory cells & present $(+)$ & absent (-). \\
\hline 28 & Secretory canals & present $(+)$ & absent (-). \\
\hline 29 & Secretory cavities & present $(+)$ & absent (-). \\
\hline \multicolumn{4}{|c|}{ Pericycle } \\
\hline 30 & Collenchyma tissue & present (+) & absent (-). \\
\hline 31 & Rosette crystals & present (+) & absent (-). \\
\hline \multicolumn{4}{|c|}{ Vascular bundle } \\
\hline 32 & Vascular bundles & complete ring $(+)$ & groups (-). \\
\hline
\end{tabular}


Table 2. continues

\begin{tabular}{|c|c|c|c|}
\hline \multicolumn{2}{|c|}{ Anatomical characters } & \multicolumn{2}{|c|}{ Character states } \\
\hline 33 & Vessels & chains $(+)$ & clusters (-). \\
\hline 34 & Tylosis & present $(+)$ & absent (-). \\
\hline \multicolumn{4}{|c|}{ Xylem } \\
\hline 35 & Rosette crystals & present $(+)$ & absent (-). \\
\hline 36 & Resin canals & present $(+)$ & absent (-). \\
\hline \multicolumn{4}{|c|}{ Medullary rays: } \\
\hline 37 & Collenchymal tissue & present $(+)$ & absent (-). \\
\hline 38 & Sclerenchymal tissue & present $(+)$ & absent (-). \\
\hline 39 & Rosette crystals & present $(+)$ & absent (-). \\
\hline 40 & Resin canals & present $(+)$ & absent (-). \\
\hline 41 & Secretory cells & present $(+)$ & absent (-). \\
\hline \multicolumn{4}{|c|}{ Phloem } \\
\hline 42 & Rosette crystals & Present $(+)$ & Absent (-). \\
\hline 43 & Sandy crystals & Present $(+)$ & Absent (-). \\
\hline 44 & Resin canals & Present $(+)$ & Absent (-). \\
\hline 45 & Secretory cells & Present $(+)$ & Absent (-). \\
\hline \multicolumn{4}{|c|}{ Pith: } \\
\hline 46 & Pith & Solid (+) & Hollow $(-)$. \\
\hline 47 & Aerenchymal tissue & Present $(+)$ & Absent (-). \\
\hline 48 & Storage parenchymal tissue & Present (+) & Absent (-). \\
\hline 49 & Sclerenchymal tissue & Present (+) & Absent (-). \\
\hline 50 & Rosette crystals & Present $(+)$ & Absent (-). \\
\hline 51 & Prismatic crystals & Present $(+)$ & Absent (-). \\
\hline 52 & Secretory cells & Present $(+)$ & Absent (-). \\
\hline 53 & Secretory canals & Present $(+)$ & Absent (-). \\
\hline 54 & Secretory cavities & Present (+) & Absent (-). \\
\hline \multicolumn{4}{|c|}{ Leaf anatomy } \\
\hline \multicolumn{4}{|c|}{ Upper epidermis : } \\
\hline 55 & Cuticle layer & Thick $(+)$ & Thin (-). \\
\hline 56 & Resin canals & Present (+) & Absent (-). \\
\hline \multicolumn{4}{|c|}{ Mesophylic tissue } \\
\hline \multicolumn{4}{|c|}{ Palisade tissue } \\
\hline 57 & Palisade tissue & One row $(+)$ & More than (-). \\
\hline 58 & " & Continuous (+) & Separated (-). \\
\hline 59 & Mucilage cells & Present $(+)$ & Absent (-). \\
\hline 60 & Rosette crystals & Present $(+)$ & Absent (-). \\
\hline 61 & Resin canals & Present $(+)$ & Absent (-). \\
\hline 62 & Laticifer tissue & Present $(+)$ & Absent (-). \\
\hline 63 & Secretory cells & Present $(+)$ & Absent (-). \\
\hline 64 & Secretory canals & Present (+) & Absent (-). \\
\hline \multicolumn{4}{|c|}{ Spongy tissue : } \\
\hline 65 & Aerenchymal tissue & Present $(+)$ & Absent (-). \\
\hline 66 & Armed Parenchymal tissue & Present $(+)$ & Absent (-). \\
\hline \multicolumn{2}{|c|}{ Anatomical characters } & Character States & \\
\hline 67 & Rosette crystals & Present $(+)$ & Absent (-). \\
\hline 68 & Resin canals & Present $(+)$ & Absent (-). \\
\hline 69 & Secretory cells & Present $(+)$ & Absent (-). \\
\hline \multicolumn{4}{|c|}{ Midrib region } \\
\hline 70 & Midripconcave lower surface $(+)$ & Straight Lower Surface (-). & \\
\hline 71 & Aerenchymal tissue & Present $(+)$ & Absent (-). \\
\hline 72 & Palisade tissue & Continuous (+) & Separated (-). \\
\hline 73 & Rosette crystals & Present $(+)$ & Absent (-). \\
\hline 74 & Resin canals & Present $(+)$ & Absent (-). \\
\hline 75 & Secretory cells & Present $(+)$ & Absent (-). \\
\hline \multicolumn{4}{|c|}{ Phloem } \\
\hline 76 & Rosette crystals & Present $(+)$ & Absent (-). \\
\hline 77 & Resin canals & Present $(+)$ & Absent (-). \\
\hline
\end{tabular}


Table 2. continues

\begin{tabular}{|c|c|c|c|c|c|}
\hline \multicolumn{6}{|c|}{$\begin{array}{l}\text { B- Multistate characters } \\
\text { Morphological characters }\end{array}$} \\
\hline 78 & Habit 3 categories: & Herbs 1 & shrubs 2 & \multicolumn{2}{|c|}{ trees 3.} \\
\hline 79 & Stem3 categories: & herbaceous 1 & woody 2 & \multicolumn{2}{|c|}{ succulent 3.} \\
\hline 80 & Leaf shapes 4 categories: & cordate 1 & elliptic 2 & oblong lanceolate 3 & ovate 4. \\
\hline 81 & Leaf arrangement : 3 categories: & spirally 1 & opposite 2 & \multicolumn{2}{|c|}{ opposite decussate 3} \\
\hline 82 & Leaf apex shape 4 categories: & acuminate 1 & obtuse 2 & caudate 3 & Mucoronta4 \\
\hline 83 & Leaf base shapes 3 categories & acute 1 & rounded 2 & \multicolumn{2}{|c|}{ cordate 3.} \\
\hline \multicolumn{6}{|c|}{ Anatomical characters } \\
\hline \multicolumn{6}{|c|}{ Stem anatomy } \\
\hline 84 & outline shapes 3 categories : & \multicolumn{2}{|c|}{ rounded 1} & tetragonal 2 & ovate 3. \\
\hline \multicolumn{6}{|c|}{ Leaf anatomy } \\
\hline 85 & Midrib region shapes 3 categories : & \multicolumn{2}{|c|}{ convex 1} & concave 2 & straight 3 . \\
\hline \multicolumn{6}{|c|}{ Vascular bundle } \\
\hline 86 & Vascular bundle shapes 3 categories & \multicolumn{2}{|l|}{ crescent 1} & ing 2 & straight3. \\
\hline
\end{tabular}

Table 3. Data matrix of observed characters for the examined plants. List of 86 characters recorded comparatively for 7 species representing 7 genera belonging to Apocynaceae.

\begin{tabular}{|c|c|c|c|c|c|c|c|c|c|c|c|c|c|c|c|c|c|c|c|c|c|c|c|c|c|c|c|c|c|c|}
\hline & 1 & 2 & 3 & 4 & 5 & 6 & 7 & 8 & 9 & 10 & 11 & 12 & 13 & 14 & 15 & 16 & 17 & 18 & 19 & 20 & 21 & 22 & 23 & 24 & 25 & 26 & 27 & 28 & 29 & 30 \\
\hline 1 & + & + & + & + & + & - & - & - & + & - & + & - & + & - & - & + & - & + & - & - & - & + & + & - & - & - & + & - & - & + \\
\hline 2 & - & + & - & + & - & + & - & - & + & - & - & - & + & + & - & + & + & - & - & + & - & - & - & - & + & + & - & - & + & - \\
\hline 3 & + & - & + & - & + & - & - & - & - & - & + & - & - & - & - & - & - & + & - & - & - & + & - & - & + & - & - & - & - & + \\
\hline 4 & + & - & + & - & + & + & - & - & + & + & - & - & - & + & + & - & - & + & - & - & - & + & + & - & + & - & + & + & + & + \\
\hline 5 & + & + & + & + & + & + & - & - & + & + & + & + & + & + & + & + & - & - & + & - & + & - & + & + & + & + & + & - & - & - \\
\hline 6 & + & + & + & + & + & + & + & - & + & - & - & + & + & - & - & + & - & - & - & - & - & + & + & + & - & - & + & + & - & + \\
\hline 7 & + & - & + & + & + & - & - & + & + & + & + & + & + & + & - & - & - & + & - & - & - & - & - & - & + & - & - & - & - & + \\
\hline
\end{tabular}

\begin{tabular}{|c|c|c|c|c|c|c|c|c|c|c|c|c|c|c|c|c|c|c|c|c|c|c|c|c|c|c|c|c|}
\hline & 31 & 32 & 33 & 34 & 35 & 36 & 37 & 38 & 39 & 40 & 41 & 42 & 43 & 44 & 45 & 46 & 47 & 48 & 49 & 50 & 51 & 52 & 53 & 54 & 55 & 56 & 57 & 58 \\
\hline 1 & + & + & + & - & + & - & + & - & - & - & - & + & - & + & + & + & + & - & - & - & - & - & - & - & + & - & + & + \\
\hline 2 & - & - & - & - & - & - & - & - & - & - & - & - & - & - & - & + & + & + & - & - & - & - & - & + & - & - & + & + \\
\hline 3 & + & + & + & + & + & - & - & + & + & + & - & + & - & + & - & - & + & - & - & + & - & - & - & - & - & - & - & - \\
\hline 4 & + & + & + & - & + & - & - & + & + & + & + & + & - & + & - & - & + & - & - & + & + & - & + & - & - & - & + & + \\
\hline 5 & - & + & + & + & - & + & + & + & - & - & + & - & + & + & + & + & + & - & + & - & + & + & - & - & + & + & + & + \\
\hline 6 & - & + & + & + & - & - & - & + & - & - & - & - & - & + & - & + & - & - & - & - & - & - & - & - & + & - & - & + \\
\hline 7 & + & + & + & - & - & + & - & + & - & + & - & - & - & + & - & + & + & - & - & + & + & - & + & - & - & - & + & - \\
\hline & 59 & 60 & 61 & 62 & 63 & 64 & 65 & 66 & 67 & 68 & 69 & 70 & 71 & 72 & 73 & 74 & 75 & 76 & 77 & 78 & 79 & 80 & 81 & 82 & 83 & 84 & 85 & 86 \\
\hline 1 & - & + & - & - & - & - & - & - & + & + & - & + & - & + & + & + & - & - & + & 3 & 2 & 4 & 3 & 1 & 2 & 1 & 3 & 1 \\
\hline 2 & - & + & - & + & - & - & + & - & - & - & - & + & + & - & + & + & - & - & - & 1 & 3 & 3 & 1 & 3 & 1 & 2 & 1 & 1 \\
\hline 3 & - & + & - & + & - & - & + & + & + & - & - & + & + & + & + & - & + & + & - & 1 & 1 & 1 & 2 & 4 & 3 & 3 & 1 & 1 \\
\hline 4 & - & + & - & - & - & + & + & + & + & - & - & + & - & - & + & + & + & - & - & 1 & 1 & 4 & 2 & 2 & 2 & 1 & 1 & 1 \\
\hline 5 & + & - & + & - & - & - & - & + & - & + & + & + & - & - & - & + & + & - & + & 3 & 2 & 2 & 1 & 1 & 1 & 1 & 1 & 2 \\
\hline 6 & + & + & - & + & + & - & + & + & + & - & + & + & + & + & + & + & + & - & - & 2 & 2 & 4 & 2 & 1 & 2 & 3 & 2 & 1 \\
\hline 7 & - & - & - & + & - & - & - & + & - & - & - & - & - & - & - & + & - & - & + & 1 & 1 & 4 & 2 & 1 & 2 & 3 & 3 & 3 \\
\hline
\end{tabular}

Table 4. Symbols used in this study.

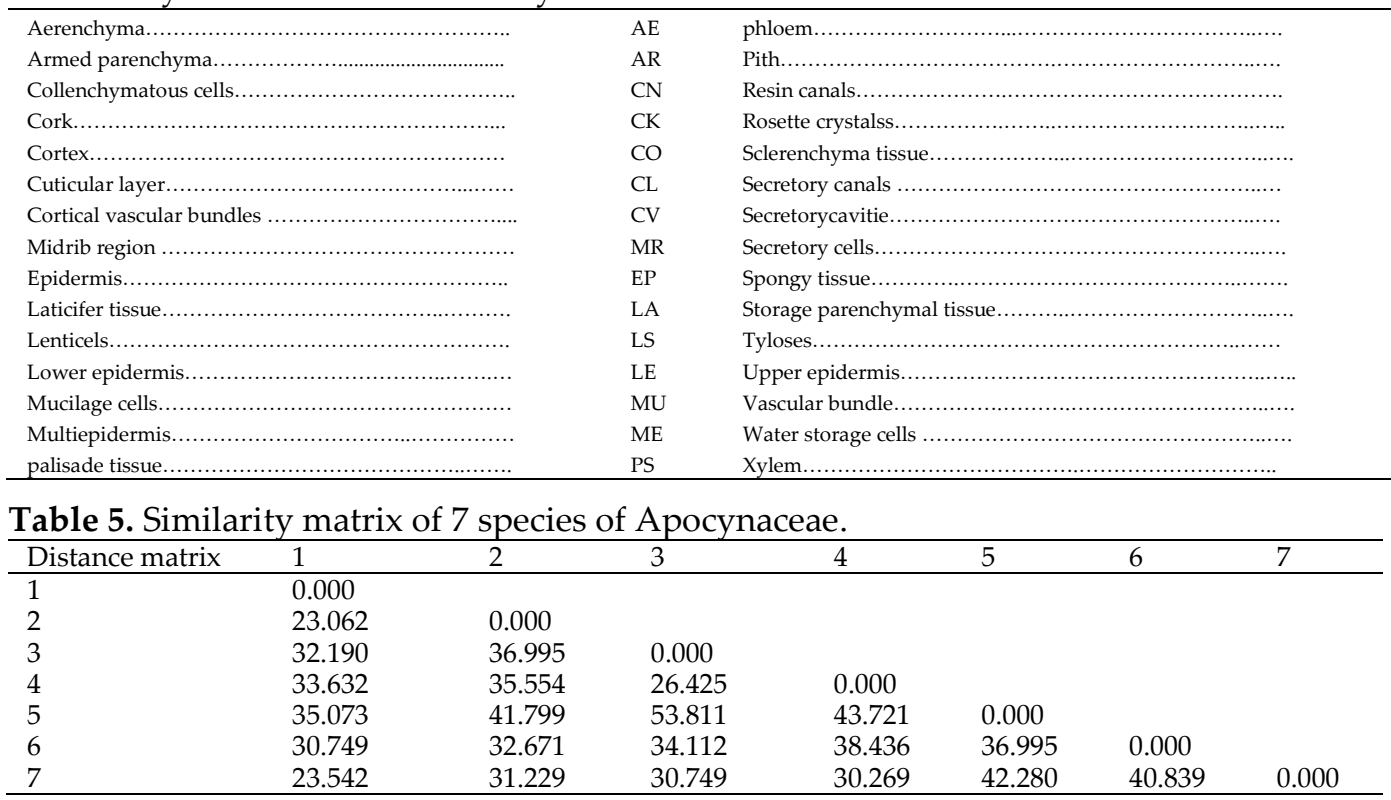




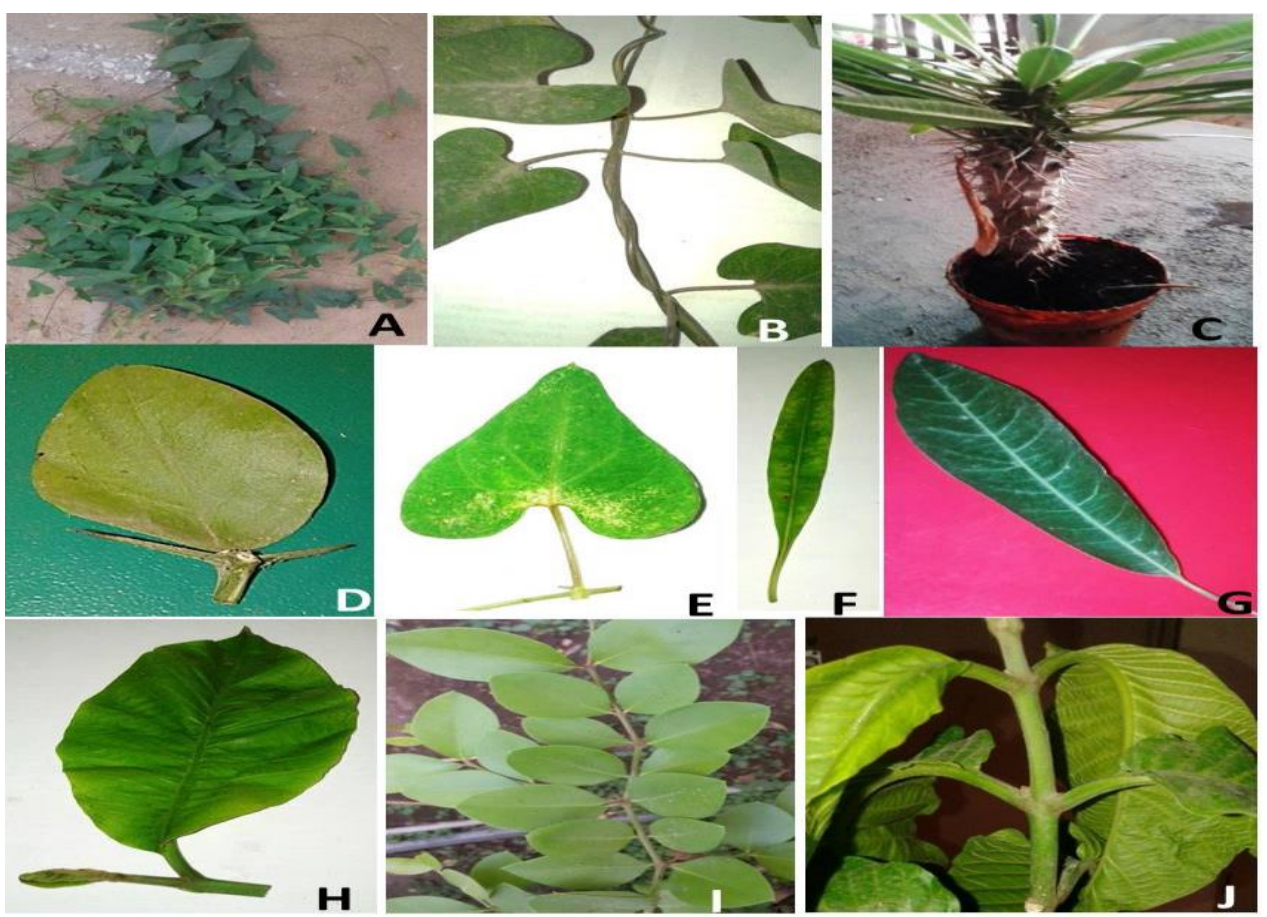

Fig. 1. Types of stem and leaf.

A. Herbaceous plants Cynanchum acutum L.; B. Weak stem C. acutum L.; C. Succulentin Pachypodium lamerei Drak. D. Stipulate leaf in Carissa spinarum L.; E. Cordate leaf in Cynanchum acutum L.; F. Oblong lanceolate leaf in P. lamerei Drak.; G. Elliptic leaf in Alstonia scholaris R.Br.; H. Acuminate in Beaumontia grandiflora Wall; I. Opposite leaf in C. spinarum L.; J. Opposite decussate leaf in B. grandiflora Wall.
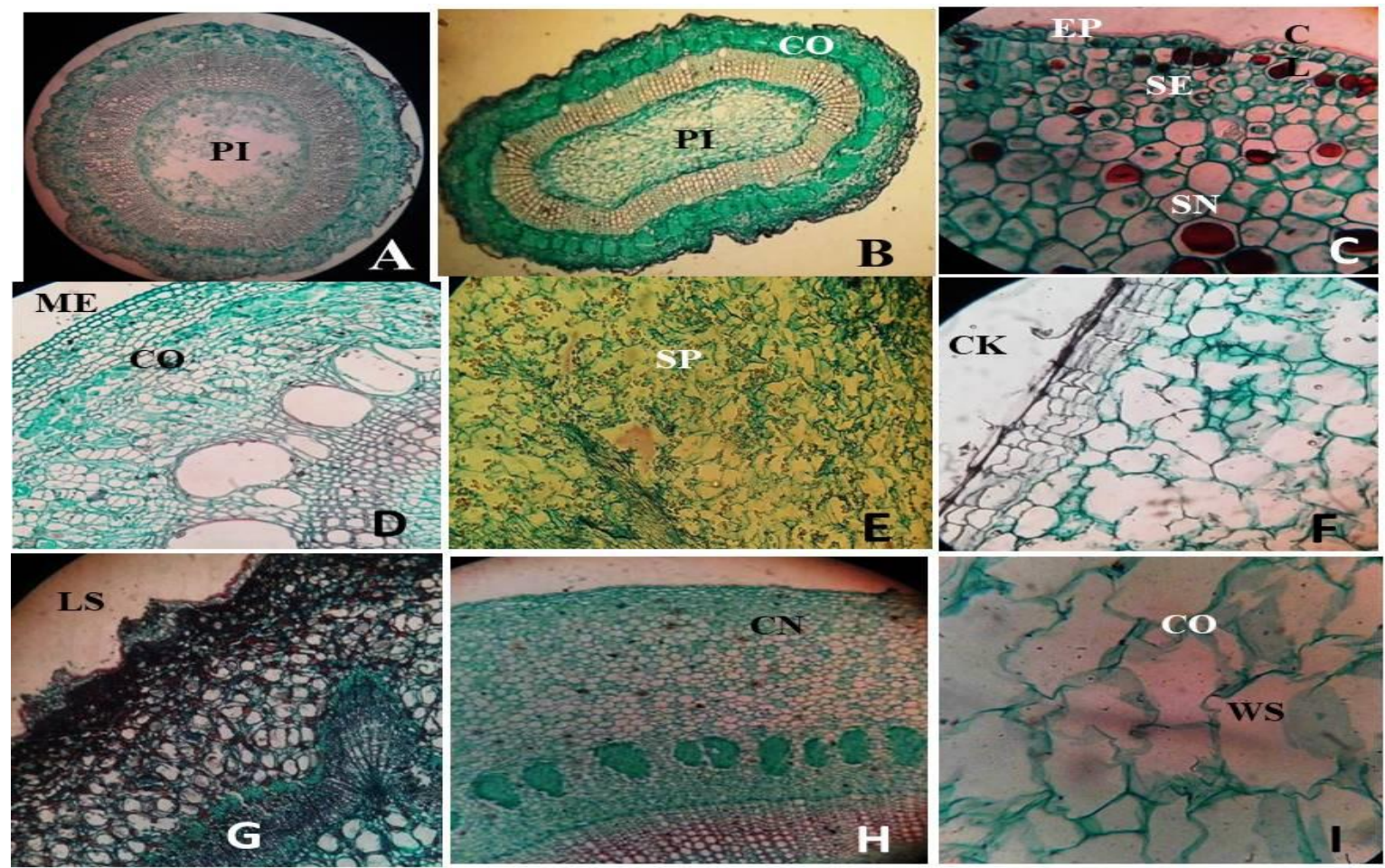

Fig. 2. Cross sections in stem of different studied species.

A. Stephanotis floribunda Brongn. $\left(\mathrm{X}_{47}\right)$; B. Cryptostegia grandi flora R.Br. $\left(\mathrm{X}_{47}\right)$; C. Carissa spinarum $\mathrm{L} .\left(\mathrm{X}_{70}\right)$; D. Cynanchum acutum $\mathrm{L} .\left(\mathrm{X}_{70}\right)$; E. Pachypodium lamerei Drake. $\left(\mathrm{X}_{70}\right)$; F. P. lamerei Drak. $\left(\mathrm{X}_{140)}\right)$; G. Alstonia scholaris R.Br. $\left(\mathrm{X}_{70}\right)$; H. Beaumontia grandiflora Wall. $\left(\mathrm{X}_{70}\right)$; I. P. lamerei Drak. (X140). 


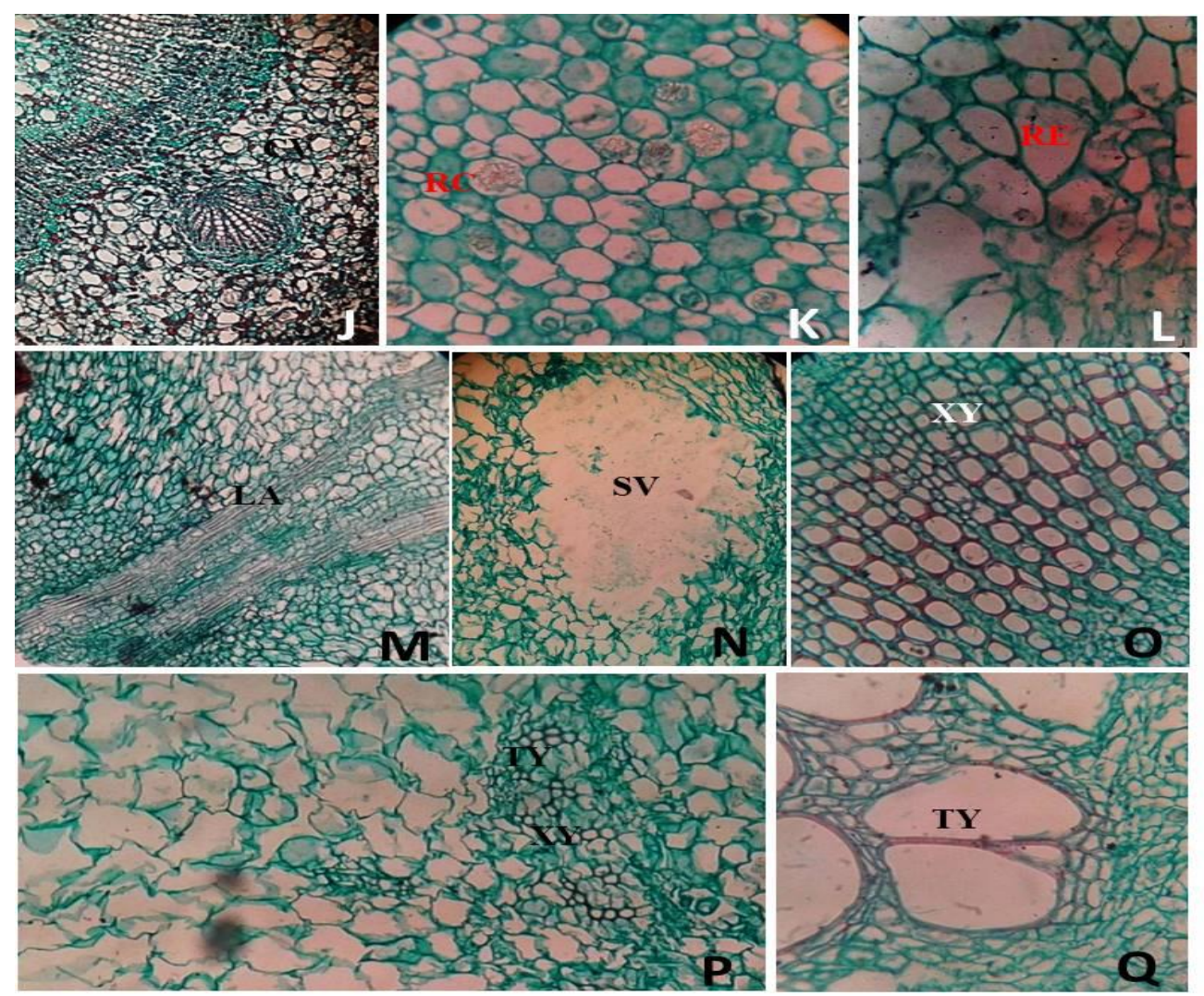

Fig. 3. Cross sections in stems of different studied species.

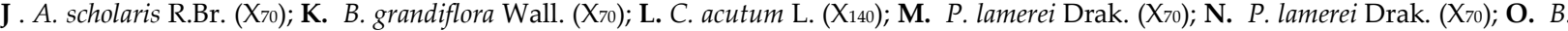
grandiflora Wall. $\left(\mathrm{X}_{140}\right)$; P. P. lamerei Drak. $\left(\mathrm{X}_{140)}\right.$; Q. C. acutum L. $\left(\mathrm{X}_{140)}\right.$.

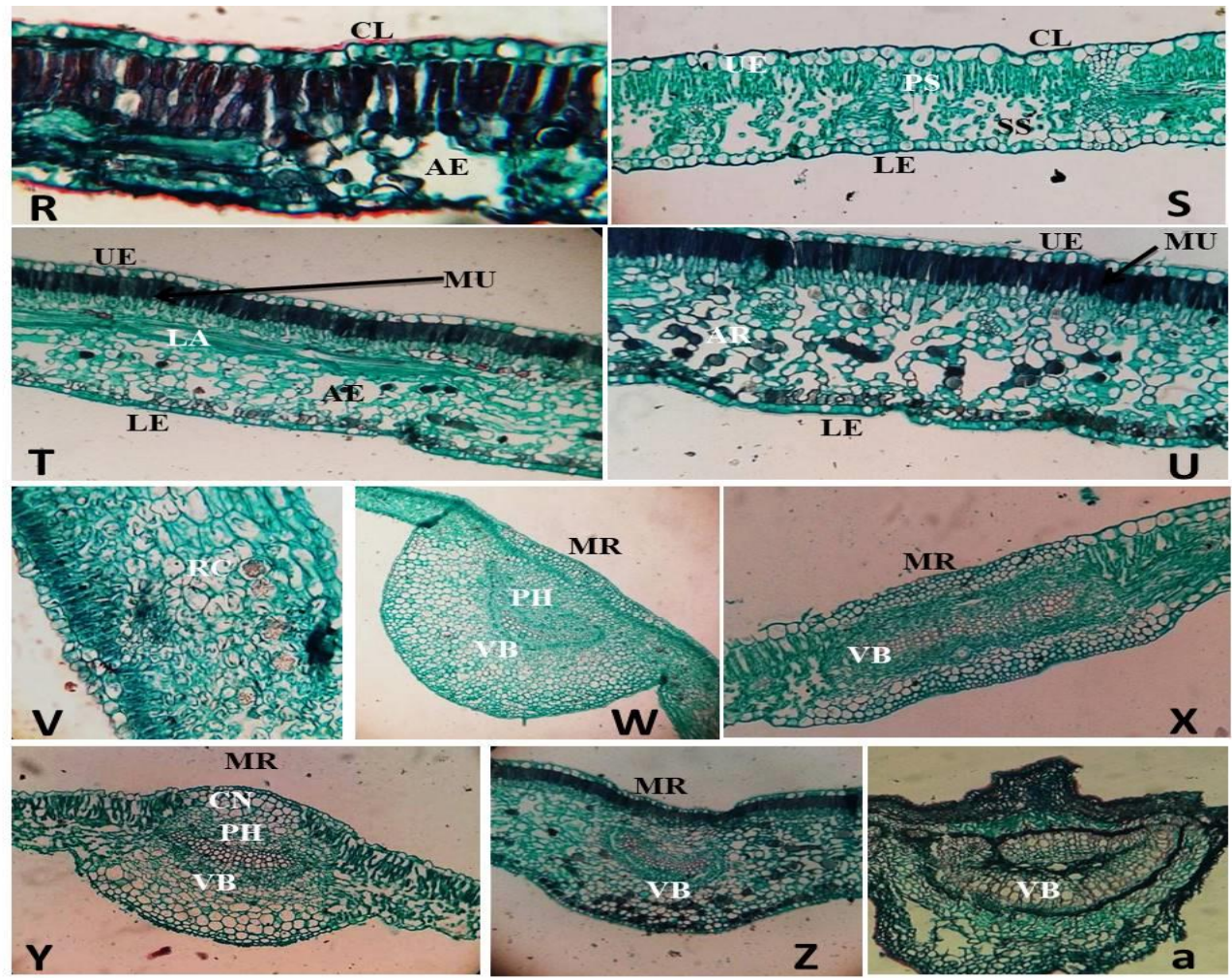

Fig. 4. Vertical sections in leaf of different studied species.

R. A. scholaris R.Br. $\left(\mathrm{X}_{70}\right)$; S. C. grandiflora R. Br. $\left(\mathrm{X}_{70}\right)$; T. C. spinarum L. $\left(\mathrm{X}_{70}\right)$; U. C. spinarum L. $\left(\mathrm{X}_{70}\right)$; V. B. grandiflora Wall. $\left(\mathrm{X}_{140)}\right)$ W. B. grandiflora Wall. $\left(\mathrm{X}_{70}\right) ; \mathrm{X}$. C. grandiflora R. Br. $\left(\mathrm{X}_{70}\right)$; Y. C. acutum L. $\left(\mathrm{X}_{70}\right)$; Z C. spinarum L. $\left(\mathrm{X}_{70}\right)$; a. A. scholaris $\mathrm{R} . \mathrm{Br}$. $\left(\mathrm{X}_{70}\right)$. 


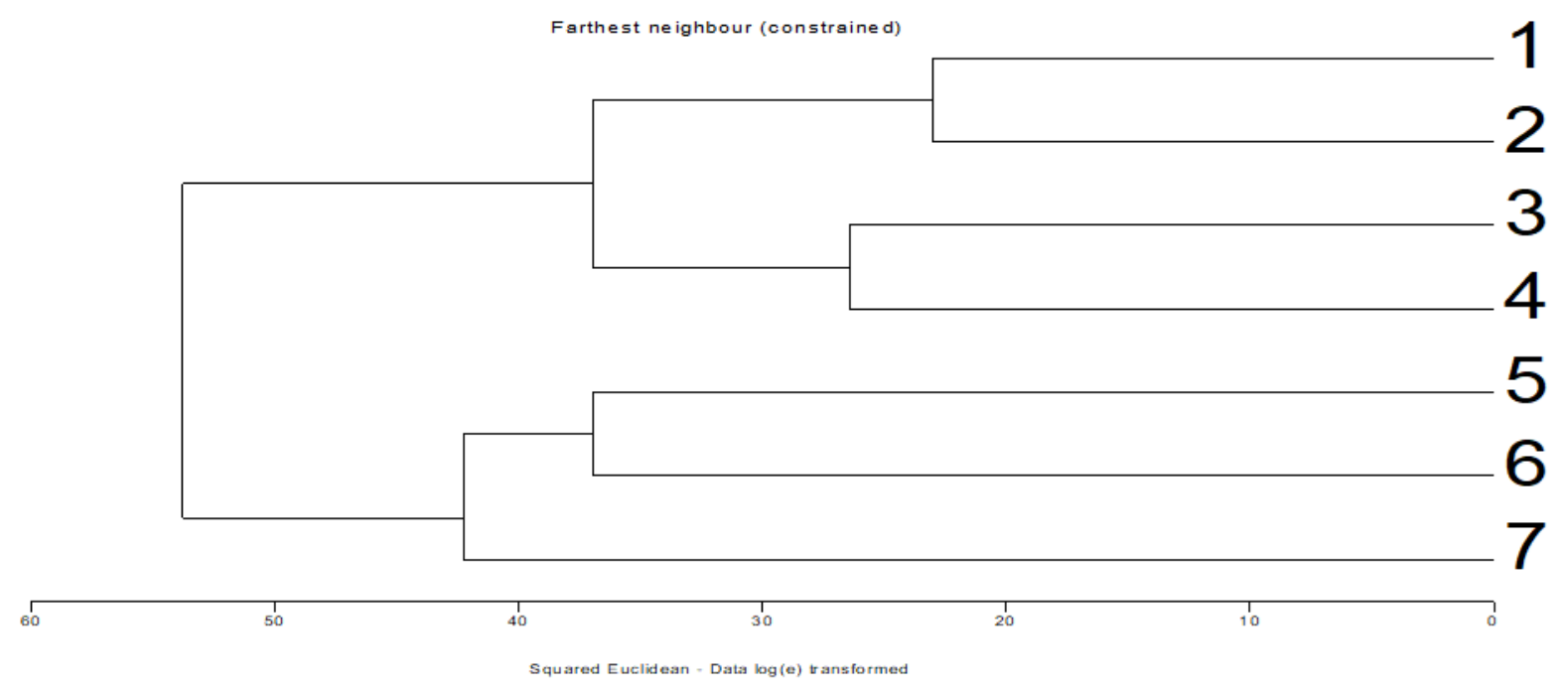

Fig. 5. Dendrogram represented the similarity and dissimilarity between 7 species belonging to Apocynaceae. 


\section{دراسات مورفولوجيا وتثريحية على بعض نباتات الفصيلة الدفلية}

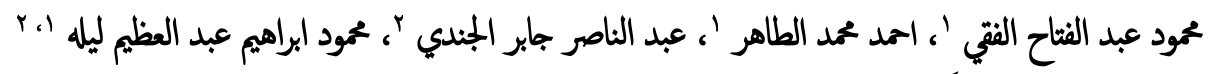

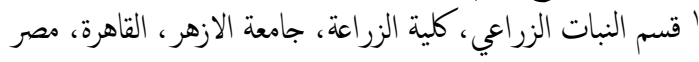

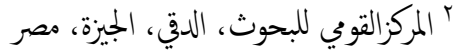

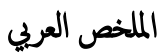

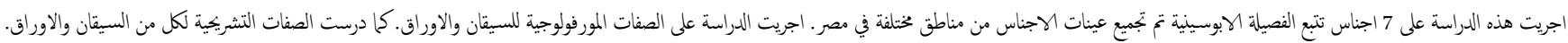

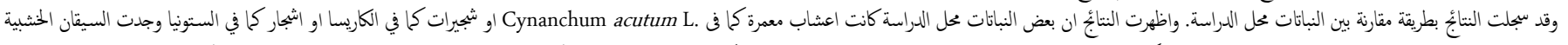

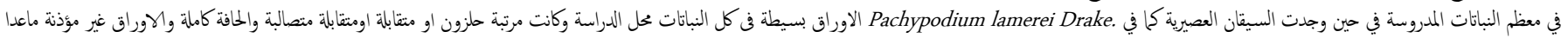

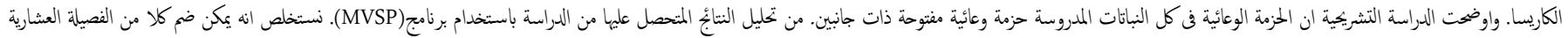

